\title{
Healthy Environmental Parameters as the Identification of Mining Entities
}

\author{
Siti Setyawati Kartika1, Raden Roro Widya Ningtyas Soeprajitno ${ }^{2 *}$ \\ 1,2Accounting Department, Airlangga University, Airlangga street no. 4-6 Surabaya, Indonesia \\ ${ }^{*}$ Corresponding author; Email: raden.roro.widya-2016@feb.unair.ac.id
}

\begin{abstract}
Nowadays, the biggest global problem in the industry sector lies in environmental issues. This issue is committed by the national entities that produce a lot of wastes and emissions. To answer this problem, the government has decided to commit to building zeroemission policies in 2050, accompanied by the appeal for disclosing and reporting the Sustainability Report for the entities in the industry sector. This research will elucidate the effort of entities involved in dealing with the global waste issue of the industrial sector. The involvement will be evaluated in the disclosure made using the applicable Global Reporting Index scale. This research utilizes mining sector entities listed in IDX from 2014 - 2018. This research uses content analysis with processing multiple linear regression and applies STATA 14. This research aims to improve the mining entities' effort, and specific parameters greatly influence the disclosure, showing the significant difference from each mining entity. This research is expected to be able to contribute to the government. Hence, they are more concerned about paying more attention and making policies to synergize the goal of "zero waste and zero-emission" by a healthy-environment-performance basis for the entities and augment the theory application knowledge development of disclosure in the form of a sustainability report.
\end{abstract}

Keywords: Environment; waste; emission; sustainability report; mining entities.

\section{INTRODUCTION}

Huge waste and emission production become the real global environmental issues from the mining entities. It is revealed that carbon emissions have already reached the level of immediate handling [27] and [38] The government copes with that severe problem by encouraging zero emission in 2050 [26]. To achieve zero emission, the government is endeavoring a variety of mandatory regulations for basic sector entities, one of which is a mining entity. The mining sector requires more attention since their business activities could impact the environmental issue attributed to the release of carbon emission.

The commitment is poured out in regulation of President Regulation Number 61 the year 2011 article 4, which mentions the contribution of business actors in GHG emissions reduction. The law indicates that entities have a responsibility to overcome the global warming issue caused by carbon emission [7], [33], and [37]. The government issues this policy to encourage the entities to become transparent about activities related to the environment as a form of their corporate responsibility [6]. They are also required to communicate their contribution in the form of a sustainability report. In Indonesia, sustainability report disclosure is still a part of an annual report, specifically, a part of the corporate social responsibility section.

According to the Global Reporting Initiative, the purpose of a sustainability report is to communicate the economic, environmental, social, and governance performance to stakeholders [27]. This report is an essential media to show their value, strategy, and commitment to a sustainable global economy, so outsiders could observe how the entities do any action related to the environment. Therefore, the disclosure must be accompanied by the awareness to issue the environmental-friendly policy [5]. This research will describe the effort and concern of entities involved in dealing with world problems evaluated in disclosures made using the applicable Global Reporting Index (GRI) scale. It is necessary since mining entities should balance their contribution to society and corporate economic performance [30].

Corporate governance generally refers to policies that govern the company's processes and structures that are related to their responsibilities [4]. According to previous research, good corporate governance could improve the tendency of emission carbon disclosure [2], [5], and [31]. This research 
will further see the impact of diversity in corporate governance on the entity's willingness to disclose the sustainability report. The researchers aim to observe the response of the board members with military connection toward waste and emission handling. Based on the preceding fact that the Indonesian government supports their military personnel's involvement in the economic sector, it issued the regulation in 1957 [29]. Since that year, military business activities have become critical in the Indonesian economy [28]. Following that fact, it is interesting to see the current situation of the military-connected board members in responding to the waste issues of mining entities.

Previous research states that firms CEOs with military or political backgrounds tend to follow the rules and respect authority and community [22] and [35]. Based on that finding, we can interpret that military-connected board members will make more effort to manage the waste from their entity since they tend to be patriotic. With that kind of consistency, they could encourage the management team to devote themselves to handle environmental issues caused by the work of mining entities since the severe environmental case itself will bring disadvantage for the country if there is no effort to handle it [21], [28], [36], and [40]

Another research supported by another research states that CEOs with military backgrounds also have more comprehensive leadership skills that could improve the overall performance of the entities. By having those characteristics, militaryconnected board members perceive the ability to make decisions properly since they tend to obey the rules and also able to decide the crisis as if the entity gets the pressure from various aspects for example in social and environmental problems of climate change [21].

Not only that, but the effect of board diversity on the effort of the entity to handle the environmental issue is also an interesting point that will be further analyzed. This paper will specifically talk about the diverse nationality and gender of the board members. It is found that foreign board members are also actively participating in board activities. It positively impacts the firms' performances since they have different perspectives on how to handle specific issues [16]. Based on the research of [22], nationality diversity plays a significant role in the company's carbon emission disclosure. The composition of foreign directors or commissioners will create heterogeneity in the experiences, ideas, and innovation [8], [9], and [24], impacting the company performance. We can assume that even though they have different nationalities, they can manage the issues since they have different life experiences and can reduce individual biases and prejudices.

Based on other literature, there is a possibility of different interpretations in facing problems if there is any communication obstacle between the board members [3], [23], [24], [26], and [32]. We assume that diverse nationalities would bring blocks in coordination to solve severe problems because of communication barriers and many perspectives that will not solve anything. Previous research explains that board diversity in terms of gender could encourage the disclosure of sustainability initiatives. Specifically, the female directors on boards voluntarily disclose the entities' information on climate change [26]. Based on the finding, we can interpret that female directors on boards tend to willingly disclose carbon emissions attributed to the entity's environmental issue.

While another research states that enhancing diversity by adding more women on boards could increase the board's independence (based on agency theory), that fact is not linked to the performance level of corporate governance in handling climate change attributed to the impact of work from mining entities [10]. Furthermore, another research states that female directors on board are likely to have ineffective monitoring of the management team; also, they are not considering the goals for the long term [18]. Based on those possible characteristics, female directors will be doubtful to take action that prevails for a long time. It seems like whether they decide to disclose the sustainability report or not is attributed to the company's efforts to manage waste and emissions.

According to the legitimacy theory, the entities have a substantial role in being responsible for societal concerns aside from their interest [12]. So, the sustainability report or the environmental contribution disclosure could legitimize their business operations. Not only that, the entities are required to participate in actions for social satisfaction, such as their effort to reduce the emission and mitigate the environmental risk [11]. Furthermore, based on this theory, entities should adapt to carrying out their business activities to suit the changing societal expectations [13]. The entities make an effort to manage waste and emission, which is being the current world environmental issue.

Our research aims to examine the characteristics of mining entities' corporate governance and give a contribution to society by voluntarily disclosing their sustainability report as their effort to be involved in dealing with the world environmental issue as in research [2], [12], and [30]. Specifically, when facing a large amount of waste 
production and emission, this research will find out voluntary disclosures that the company made by using a sample of 39 mining companies listed in the IDX from 2014-2018. This research will employ content analysis with multiple linear regression processing using STATA-14 software. Data related to military connection, nationality, and gender are obtained from the profiles of the board of commissioners and board of directors that can be found in the annual report. Furthermore, we exert financial-related data from financial statements for some variables such as firm size, leverage, current ratio, and return on equity.

This research indicates an enhancement of improvement effort and the disclosure strongly influenced by the specific parameters contained therein, thus indicating a significant difference from each mining company. Companies with governance structures consisting of military connections and females tend to reduce their carbon emission disclosure performance, and vice versa from that displayed by foreign. But in the end, all the improvement effort done by the mining entities intends to gradually achieve zero-emission, expected to bring good impact to society and the environment.

This study contributes to the development of literature related to corporate governance and the disclosure of their reports. This research's implication is intended to contribute to the management and be considered the governance structures that may be beneficial to the company and the environment. In addition, the government could pay more attention and give concern to the performance of entities that might endanger the environment.

The remainder of this paper will be arranged as follows: Section 2 describes variables, samples, and research model; Section 3 presents empirical analysis and research results, and Section 4 lays out a summary and conclusion from the research.

\section{RESEARCH METHOD}

The method includes information for the readers to follow the research flow well. The reader who will examine or develop similar research obtains the description of the research steps. Aligned with the purpose of the study, this research uses a quantitative method. The researchers study the background of the problems and the actual condition of the issues nowadays or the research object. This research will elucidate the effort of entities involved in dealing with the global waste issue of the industry sector. The involvement will be evaluated in the disclosure made using the applicable Global Reporting Index scale. This research utilizes mining sector entities listed in IDX from 2014 - 2018.
Furthermore, this research uses content analysis with processing multiple linear regression and applies STATA 14. The researchers will evaluate each company listed in the IDX based on the information in the annual reports and in the sustainability reports and consider it [2], [5], and [19]. In this study, the sample is 39 mining entities listed on the Indonesia Stock Exchange, and the number of observational models from 2014 to 2018 is 178 samples. The number is relatively small because Indonesia is still a developing country that is not required to reduce greenhouse gas emissions [13]. In addition, the disclosure of carbon emission information is still voluntary in Indonesia, not an obligation. However, the literature states that as companies get older, they will disclose more about their reputation and increase their disclosure. In this case, they will reveal more about their environmental program related to carbon emission [15] and [34].

\section{Measurement}

\section{Dependent Variable Carbon Emission Dis- closure}

The dependent variable is the disclosure of the carbon emission in the company using the checklist developed by [5]. The researchers will check several points in the Carbon Emission Disclosure list that has already been determined to evaluate the extent of the company to disclose their climate change and carbon emission voluntarily. With the list, the maximum point the company can get is 18 . The checklist is divided into five categories, where each category has its items that need to be fulfilled.

Table 1. Carbon Emission Disclosure Checklist

\begin{tabular}{cc}
\hline \multicolumn{1}{c}{ Carbon Emission Accountability } \\
\hline CC1 - & $\begin{array}{l}\text { assessment/description of the risks (regulatory, } \\
\text { physical or general) relating to climate change } \\
\text { and actions are taken or to be taken to manage } \\
\text { the risk. }\end{array}$ \\
CC2 - & $\begin{array}{c}\text { assessment/description of current (and future) } \\
\text { financial implications, business implications, } \\
\text { and opportunities of climate change }\end{array}$ \\
\hline GHG Emissions Accounting \\
GHG1 - description of the methodology used to calculate \\
GHG emissions (e.g., GHG protocol or ISO) \\
GHG2 - existence external verification of quantity of \\
GHG emission- if so by whom and on what \\
basis \\
GHG3 - total GHG emissions - metric tonnes CO2-e \\
emitted. \\
GHG4 - disclosure of Scopes 1 and 2, or Scope 3 direct \\
GHG emissions \\
GHG5 - disclosure of GHG emissions by sources (e.g., \\
coal, electricity, etc.) \\
GHG6 - disclosure of GHG emissions by facility or \\
segment level \\
GHG7 - comparison of GHG emissions with previous \\
years
\end{tabular}




\begin{tabular}{ll}
\hline $\mathrm{EC} 1-$ & \multicolumn{1}{c}{ Energy Consumption Accounting } \\
joules) \\
$\mathrm{EC} 2-$
\end{tabular}

\section{Independent Variable Military Connection}

The independent variable that the researchers use is military connection. The researchers choose to use this variable based on previous research. It is stated that CEOs of firms with a military background tend to follow the rules and be stricter on following the authority and community [24]. The researchers expect that companies with a military connection will make more effort to manage their waste and disclose more about their waste management. The measurement of military connection in the company is a dummy; one of the commissioners or directors has a military connection and 0 otherwise.

\section{National Diversity}

The researchers choose to use diversity in nationality because the prior research from [16] states that nationality diversity plays a significant role in the company's carbon emission disclosure. The relationship between the proportion of foreign directors or commissioners will cause a causality in heterogeneity in the experiences, ideas, and innovation [8], [9], and [24], which affects the company performance. Therefore, the measurement of national diversity is the proportion of numbers from foreign nationality divided by the total number from commissioner and director [16].

\section{Gender Diversity}

The researchers choose to use gender diversity because, based on the previous research, it is explained that the board diversity in terms of gender could encourage sustainability initiatives.
Specifically, the female directors on boards voluntarily disclose the entities' climate change information because the nature of women is more open and soft [1] [26]. However, other research states that female directors on board have an inclination to not consider the goals for the long term and have an ineffective monitoring of the management team [18] that will affect the carbon emission disclosure. This measurement from gender diversity uses dummy variables following the research by [16], one if there is female and male in the board of commissioner or director and 0 otherwise.

\section{Control Variable}

The researchers use several control variables such as the size of the firms, leverage, current ratio, and ROE using the Earnings before Interest and Tax. These variables follow the accounting literature in [2], [8], [10], [17], [20], [24], [38] and [39]. The bigger the entities are, the more attention they will get from the public. It will make them more conscious and under pressure about their social activity disclosure. The entities' size can be evaluated by using the natural logarithm of entities' total assets [5]. The higher the reliability of entities to the fund from creditors, the stronger the possibility of the entities to fulfill the creditors' hope for the carbon emission problems and climate change. The study finds that the high level of entity leverage will increase the disclosure of carbon emission.

For the current ratio and ROE_EBIT, it will show the entity's performance. Corporate Social Responsibility is recognized as a kind of corporate investment that creates opportunities to enhance organizational financial performance in the future. So, socially environmentally responsible companies are likely to be viewed more favorably by investors [14]. The previous research stated that the company's performance would positively associate with the carbon emission disclosure. The following in Table 2 shows the definition variables that this study uses.

\section{Operational Variables' Definition}

Table 2. Operational Variables' Definition

\begin{tabular}{ll}
\hline VARIABLES & \multicolumn{1}{c}{ DEFINITION } \\
\hline Dependent & \\
\hline CED_SCORE & $\begin{array}{l}\text { Carbon Emission Disclosure, proxy by } \\
\text { using the checklist by Chen } \text { et al., }\end{array}$ \\
\hline Independent & \\
\hline MCON & $\begin{array}{l}\text { The military connection in the company, } \\
\text { whether the commissioners or directors, } \\
\text { have a military connection. } 1 \text { if the com- } \\
\text { missioners or directors have a military } \\
\text { connection and 0 otherwise. }\end{array}$ \\
\hline
\end{tabular}




\begin{tabular}{ll}
\hline FRG & $\begin{array}{l}\text { The proportion of number or foreign } \\
\text { nationality divided by the total number } \\
\text { from commissioner and director } \\
1 \text { if there is a female on the board of } \\
\text { commissioner or director and 0 other- } \\
\text { wise. }\end{array}$ \\
\hline Control & \\
\hline FSIZE & $\begin{array}{l}\text { The natural algorithm of total assets of } \\
\text { the entities to find the size of the } \\
\text { entities. } \\
\text { The }\end{array}$ \\
CUR_RAT & $\begin{array}{l}\text { The total debt is divided by total assets } \\
\text { Current assets are divided by current } \\
\text { liabilities. }\end{array}$ \\
ROE_EBIT & $\begin{array}{l}\text { Return on equity by using the earnings } \\
\text { before interest and tax, calculated by } \\
\text { dividing total earnings before interest } \\
\text { and tax to total equity. }\end{array}$ \\
\hline
\end{tabular}

This research is based on the previous study and wants to prove three hypotheses:

1. Military connection influences the entities' effort to support a healthy environment free from waste and emission.

2. Foreign influences the entities' effort to support a healthy environment that is free from waste and emission.

3. Gender influences the entity's effort to support a healthy environment free from waste and emission.

The model for the research is:

\section{CED_SCORE $=a+B_{1} \mathrm{MCON}+B_{2} \mathrm{FRG}+\mathrm{B}_{3} \mathrm{GEN}+$ $B_{4} \mathrm{FSIZE}+B_{5} \mathrm{LEV}+$ b $_{6} \mathrm{CUR} \_\mathrm{RAT}+$ ${ }_{7} \mathrm{ROE} \_\mathrm{EBIT}+\varepsilon$ \\ RESULTS AND DISCUSSION}

This research uses 178 mining entities from 2014-2018 listed in the Indonesia Stock Exchange (IDX) as samples. Table 3 shows the sample distribution for each year from all the samples used. This table shows that the sample distribution in 2018 is the lowest with the frequency of 33 samples. Being in the sample distribution range of 33 until 37 indicates that our sample distribution does not show a gap in the sample observations for each year.

Table 3. Sample Distribution based on year

\begin{tabular}{lccc}
\hline Year & Freq. & Percentage & Cumulative \\
\hline 2014 & 37 & 20.79 & 20.79 \\
2015 & 35 & 19.66 & 40.45 \\
2016 & 38 & 21.35 & 61.80 \\
2017 & 35 & 19.66 & 81.46 \\
2018 & 33 & 18.54 & 100.00 \\
\hline
\end{tabular}

Table 4. Descriptive Statistics shows that the maximum score for CED is 0,722 from the total of
18 indicators that the entities can achieve, and the average amount of CED score is 0,222 . This implies that mining companies are less likely to disclose their carbon emission reports. The figure is shown in the maximum disclosure that also has not reached the maximum score it should be.

Table 4. Descriptive Statistics

\begin{tabular}{lcccc}
\hline & Mean & Median & Minimum & Maximum \\
\hline SKORCED & 0.268 & 0.222 & 0.000 & 0.722 \\
MCON & 0.339 & 0.000 & 0.000 & 1.000 \\
FRG & 0.171 & 0.140 & 0.000 & 0.667 \\
GEN & 0.465 & 0.000 & 0.000 & 1.000 \\
FSIZE & 25.179 & 24.604 & 20.239 & 30.156 \\
LEV & 0.537 & 0.436 & 0.104 & 1.856 \\
CUR_RAT & 1.200 & 0.729 & 0.090 & 5.700 \\
ROE_EBIT & 6.369 & 2.420 & -34.440 & 48.540 \\
\hline
\end{tabular}

Table 5. Pearson Correlation shows that the three categories will show the result of a good relationship. The categories are being labeled with $*, * *, * * *$. The more stars it has, the better the relationship. In this case, * shows that the level of significance is $10 \%$, ** shows that the level of significance is $5 \%$, and $* * *$ shows that the level of significance is $1 \%$. The negative sign shows the reverse relationship, and the positive sign shows the direct relationship. From the table below, it can be concluded that FRG, FSIZE, and ROE_EBIT have a positive relationship with the CED SCORE while MCON, GEN, LEV, and CUR_RAT have a negative relationship with the CED SCORE. Even though we have tested one variable to another, the inherent nature of the data that we have has a significant effect on the dependent variable of this study. This is interesting in further testing in the modeling that we make in this study.

Table 6 . The result of linear regression indicates the influence of independent variables toward dependent variables, which is proxied by CED_SCORE representing the quality of the performance of mining entities in supporting healthy environmental efforts from entity waste production and emissions. This table shows that the entities that are serious in their efforts to deal with waste problems are more likely to be represented by entities with foreign nationality board members in Indonesia. Discovered from the results of the regression to answer the second hypothesis shows a significant influence at the level of $1 \%$ and positive with a coefficient of 0.275 , so this finding supports the previous research by [16] that states nationality diversity plays a significant role in the company's carbon emission disclosure. 
Table 5. Pearson Correlation

\begin{tabular}{|c|c|c|c|c|}
\hline & SKOR_CED & MCON & FRG & GEN \\
\hline$\overline{\text { SKOR_CED }}$ & 1.000 & & & \\
\hline $\mathrm{MCON}$ & $\begin{array}{c}-0.249^{* * *} \\
(0.000)\end{array}$ & 1.000 & & \\
\hline FRG & $\begin{array}{l}0.335^{\text {*** }} \\
(0.000)\end{array}$ & $\begin{array}{c}-0.144^{* *} \\
(0.029)\end{array}$ & 1.000 & \\
\hline GEN & $\begin{array}{l}-0.169^{* *} \\
(0.010)\end{array}$ & $\begin{array}{l}-0.018 \\
(0.786)\end{array}$ & $\begin{array}{c}0.076 \\
(0.251)\end{array}$ & 1.000 \\
\hline FSIZE & $\begin{array}{l}0.476^{\text {*** }} \\
(0.000)\end{array}$ & $\begin{array}{l}-0.093 \\
(0.158)\end{array}$ & $\begin{array}{l}0.212^{* * *} \\
(0.001)\end{array}$ & $\begin{array}{c}-0.004 \\
(0.953)\end{array}$ \\
\hline LEV & $\begin{array}{c}-0.206^{\star \star *} \\
(0.002)\end{array}$ & $\begin{array}{l}-0.006 \\
(0.926)\end{array}$ & $\begin{array}{c}-0.061 \\
(0.356)\end{array}$ & $\begin{array}{l}0.370^{* * *} \\
(0.000)\end{array}$ \\
\hline CUR_RAT & $\begin{array}{l}-0.123^{*} \\
(0.063)\end{array}$ & $\begin{array}{c}0.200^{* * *} \\
(0.002)\end{array}$ & $\begin{array}{c}0.032 \\
(0.631)\end{array}$ & $\begin{array}{c}-0.194^{* * *} \\
(0.003)\end{array}$ \\
\hline ROE_EBIT & $\begin{array}{l}0.165^{* *} \\
(0.012) \\
\end{array}$ & $\begin{array}{c}0.094 \\
(0.157) \\
\end{array}$ & $\begin{array}{c}0.075 \\
(0.254) \\
\end{array}$ & $\begin{array}{c}0.070 \\
(0.288) \\
\end{array}$ \\
\hline & FSIZE & LEV & CUR_RAT & ROE_EBIT \\
\hline$\overline{\text { FSIZE }}$ & 1.000 & & & \\
\hline LEV & $\begin{array}{l}-0.056 \\
(0.395)\end{array}$ & 1.000 & & \\
\hline CUR_RAT & $\begin{array}{l}-0.089 \\
(0.177)\end{array}$ & $\begin{array}{c}-0.193^{* * *} \\
(0.003)\end{array}$ & 1.000 & \\
\hline ROE_EBIT & $\begin{array}{c}0.081 \\
(0.218) \\
\end{array}$ & $\begin{array}{l}-0.100 \\
(0.131)\end{array}$ & $\begin{array}{r}-0.058 \\
(0.383)\end{array}$ & 1.000 \\
\hline
\end{tabular}

Table 6. Linear Regression Result

\begin{tabular}{lccc}
\hline & $(1)$ & $(2)$ & $(3)$ \\
& SKOR_CED & SKOR_CED & SKOR_CED \\
\hline MCON & $-0.094^{* * *}$ & & \\
FRG & $(-3.67)$ & & \\
& & $0.275^{* * *}$ & \\
GEN & & $(4.23)$ & \\
& & & $-0.049^{* *}$ \\
FSIZE & & & $(-2.44)$ \\
& $0.028^{* * *}$ & $0.026^{* * *}$ & $0.030^{* * *}$ \\
LEV & $(7.72)$ & $(7.07)$ & $(7.92)$ \\
& $-0.101^{\text {*** }}$ & $-0.101^{* * *}$ & $-0.076^{* *}$ \\
CUR_RAT & $(-3.26)$ & $(-3.29)$ & $(-2.27)$ \\
& -0.011 & $-0.020^{* *}$ & $-0.021^{* *}$ \\
ROE_EBIT & $(-1.23)$ & $(-2.24)$ & $(-2.28)$ \\
& $0.001^{* *}$ & 0.001 & $0.001^{* *}$ \\
cons & $(2.27)$ & $(1.62)$ & $(2.07)$ \\
& $-0.358^{* * *}$ & $-0.369^{* * *}$ & $-0.395^{* * *}$ \\
\hline r2 & $(-3.62)$ & $(-3.79)$ & $(-3.97)$ \\
r2_a & 0.324 & 0.336 & 0.302 \\
$N$ & 0.309 & 0.321 & 0.286 \\
\hline
\end{tabular}

$t$ statistics in parentheses

${ }^{*} p<0.1,{ }^{* *} p<0.05,{ }^{* * *} p<0.01$

This research also acknowledges the first hypothesis, namely entities that have a military connection significantly affect the level of $1 \%$ on the quality of the seriousness of the entity supporting the efforts of a healthy environment proxied by CED_SCORE and negative on entities with a coefficient of 0.094 . This happens because military backgrounds tend to follow the rules, respect authority and community. The analysis using the legitimacy theory shows that the behavior caused by governance with military connections negates the opportunity to build their legitimacy for free.
They agree on how to improve their reputation by following the existing mandatory practices.

In the third hypothesis, it can be seen that an entity with a female gender top manager will have a significant effect at the 5\% level and negatively on CED_SCORE with a coefficient of 0.049. This hypothesis also indicates that female board members will negatively affect the quality of the company's seriousness in managing waste and emissions. This corresponds to the previous research that states female directors on board tend to not consider the goals for the long term and have ineffective monitoring of the management team [18]. In the legitimacy theory, the reputation built by the company is deemed necessary to build. But under certain conditions, the presence of women in governance may be fulfilled by considering the benefits obtained by the amount of cost they incur. Therefore, it is very natural that the presence of women will negatively affect the disclosure of their reports.

\section{CONCLUSIONS}

Based on this research, it can be concluded that military connection, nationality, and gender play a significant role in carbon emission disclosure. The military connection will negatively affect the carbon emission disclosure because the military background is relatively more oriented to follow the rules, respect authority, and community. The nationality diversity also brings a negative effect to the carbon emission disclosure. It shows that a foreign board of directors or commissioners will increase the carbon emission disclosure. Lastly, gender has a positive effect on carbon emission disclosure. The result shows that the female board members will positively affect the carbon emission disclosure.

This research has limitations. This research does not use a sample that can describe the general condition of companies in Indonesia, but this research can provide an overview of the mining companies. This research needs to be carried out with a robustness test to ensure the results are free from specific conditions and problems.

\section{REFERENCES}

[1] Adamson, L., Als, H., Tronick, E., \& Brazelton, T. B. (1977). The Development of Social Reciprocity between a Sighted Infant and Her Blind Parents: A Case Study. Journal of the American Academy of Child Psychiatry, 16(2), 194-207. https://doi.org/ 10.1016/S0002-7138 (09)60036-4. 
[2] Bae, B., Doowon, C., Jim, L., Choi, B. B., Lee, D., \& Psaros, J. (2014). An analysis of Australian company carbon emission disclosures. https://doi.org/10.1108/01140581311318968

[3] Benjamin, S. J., \& Biswas, P. (2019). Board gender composition, dividend policy and COD: the implications of CEO duality. Accounting Research Journal, 32(3), 454-476. https://doi. org/10.1108/ARJ-02-2018-0035

[4] Butar Butar, S. (2020). The effects of Corporate Governance, Audit Quality, and Conservatism on Loan Collateral Requirements. Jurnal Akuntansi Dan Keuangan, 22(1), 2839. https://doi.org/10.9744/jak.22.1.28-39

[5] Choi, B. B., Lee, D., \& Park, Y. (2013). Corporate Social Responsibility, Corporate Governance and Earnings Quality: Evidence from Korea. Corporate Governance: An International Review, 21(5), 447-467. https://doi. org/ 10.1111/corg.12033

[6] Darmadi, S., \& Sodikin, A. (2013). Information disclosure by family-controlled firms: The role of board independence and institutional ownership. Asian Review of Accounting, 21(3), 223-240. https://doi.org/10.1108/ARA-01-20130009

[7] Dawkins, C., \& Fraas, J. W. (2011). Coming Clean: The Impact of Environmental Performance and Visibility on Corporate Climate Change Disclosure. 303-322. https://doi.org/ 10.1007/s10551-010-0681-0

[8] Estélyi, K. S., \& Nisar, T. M. (2016). Diverse boards: Why do firms get foreign nationals on their boards? Journal of Corporate Finance, 39, 174-192. https://doi.org/10.1016/j.jcorpfin. 2016.02.006

[9] Fields, M. A., \& Keys, P. Y. (2003). The emergence of corporate governance from Wall St. to Main St.: Outside directors, board diversity, earnings management, and managerial incentives to bear risk. Financial Review, 38(1), 124.

[10] Galbreath, J. (2018). Is Board Gender Diversity Linked to Financial Performance? The Mediating Mechanism of CSR. Business and Society, 57(5), 863-889. https://doi.org/10. 1177/000765031664796

[11] Ganda, F., \& Ngwakwe, C. C. (2013). The contribution of environmental, social, and governance disclosure to a sustainable economy. 2137. https://doi.org/10.1007/s40483-013-0004-z

[12] Guthrie, J., \& Parker, L. D. (1989). Corporate Social Reporting: A Rebuttal of Legitimacy Theory. Accounting and Business Research, 19(76), 343-352. https://doi.org/10.1080/000 14788.1989.9728863

[13] Hermawan, A., Aisyah, I. S., Gunardi, A., \& Putri, W. Y. (2018). Going green: Determinants of carbon emission disclosure in manufacturing companies in Indonesia. Internatio- nal Journal of Energy Economics and Policy, 8(1), 55-61.

[14] Hoepner, A., Oikonomou, I., Scholtens, B., \& Schröder, M. (2016). The effects of corporate and country sustainability characteristics on the cost of debt: An international investigation. Journal of Business Finance \& Accounting, 43(1-2), 158-190.

[15] Khan, H. U. Z. (2010). The effect of corporate governance elements on corporate social responsibility (CSR); reporting: Empirical evidence from private commercial banks of Bangladesh. International Journal of Law and Management, 52(2), 82-109. https://doi. org/10.1108/17542431011029406

[16] Kılıç, M., \& Kuzey, C. (2019). The effect of corporate governance on carbon emission disclosures: Evidence from Turkey. International Journal of Climate Change Strategies and Management, 11(1), 35-53. https://doi.org/10. 1108/IJCCSM-07-2017-0144

[17] Kuo, L., Chen, V. Y., \& Chen, V. Y. (2013). Is environmental disclosure an effective strategy on establishment of environmental legitimacy for organization? https://doi.org/10.1108/MD06-2012-0395

[18] Lee, R. (2014). Board Diversity and Corporate Social Responsibility. https://doi.org/10.1007/ s10551-014-2343-0

[19] Lee, S., Park, Y., \& Klassen, R. D. (2013). Market Responses to Firms' Voluntary Climate Change Information Disclosure and Carbon Communication. https://doi.org/10.1002/csr.1321

[20] Liao, L., Luo, L., \& Tang, Q. (2014). Gender diversity, board independence, environmental committee and greenhouse gas disclosure $\mathrm{q}$. The British Accounting Review, 1-16. https://doi.org/10.1016/j.bar.2014.01.002

[21] Lin, C., Ma, Y., Officer, M. S., \& Zou, H. (2012). CEOs' Military Experience and Acquisition Decisions. SSRN Electronic Journal. https://doi.org/10.2139/ssrn.1932623

[22] Lin, P. T. (2014). The effects of board mechanisms and ownership on the relationship between ceo duality and earnings management in china's listed companies. Corporate Ownership and Control, 11(4 A), 18-27. https://doi.org/10.22495/cocv11i4p2

[23] Matuszak, Ł., Różańska, E., \& Macuda, M. (2019). The impact of corporate governance characteristics on banks' corporate social responsibility disclosure: Evidence from Poland. Journal of Accounting in Emerging Economies, 9(1), 75-102. https://doi.org/10.1108/ JAEE-04-2017-0040.

[24] McGuinness, P. B., Vieito, J. P., \& Wang, M. (2017). The role of board gender and foreign 
ownership in the CSR performance of Chinese listed firms. Journal of Corporate Finance, 42, 75-99. https://doi.org/10.1016/j.jcorpfin.2016. 11.001

[25] Miletkov, M. K., Poulsen, A. B., \& Wintoki, M. B. (2014). The role of corporate board structure in attracting foreign investors. Journal of Corporate Finance, 29, 143-157.

[26] Millicent, W. B., \& Philip, C. (2015). Board Gender Diversity and Corporate Response to Sustainability Initiatives: Evidence from the Carbon Disclosure Project. Journal of Business Ethics. https://doi.org/10.1007/s10551015-2759-1

[27] Nasih, M., Harymawan, I., \& Paramitasari, Y. I. (2019). Carbon Emissions, Firm Size, and Corporate Governance Structure: Evidence from the Mining and Agricultural Industries in Indonesia.

[28] Nasih, M., Harymawan, I., Putra, F. K. G., \& Qotrunnada, R. (2019). Military experienced board and corporate social responsibility disclosure: An empirical evidence from Indonesia. Entrepreneurship and Sustainability Issues, 7(1), 553-573. https://doi.org/10.9770/ jesi. 2019.7.1(39).

[29] Ngoc Phi Anh, D., \& Nguyen, D. (2013). Accounting in a developing transitional economy: The case of Vietnam. Asian Review of Accounting, 21(1), 74-95. https://doi.org/10. 1108/13217341311316959.

[30] Oestreich, A. M., \& Tsiakas, I. (2015). Carbon emissions and stock returns: Evidence from the EU Emissions Trading Scheme. Journal of Banking Finance, 58, 294-308. https://doi. org/10.1016/j.jbankfin.2015.05.005.

[31] Rankin, M., Windsor, C., \& Wahyuni, D. (2011). An investigation of voluntary corporate greenhouse gas emissions reporting in a market governance system Australian evidence. https://doi.org/10.1108/09513571111184751.

[32] Rao, K., \& Tilt, C. (2015). Board Composition and Corporate Social Responsibility: The Role of Diversity, Gender, Strategy and Decision Making. https://doi.org/10.1007/s10551-0152613-5.

[33] Robert, A. (2011). Climate change disclosures: An examination of Canadian oil and gas firms. 5(1), 106-123.

[34] Sharma, J. P., \& Khanna, S. (2014). Corporate social responsibility, corporate governance and sustainability: Synergies and interrelationships. In Indian Journal of Corporate Governance (Vol. 7, Issue 1, pp. 14-38). https://doi. org/10.1177/097468622014010.

[35] Sharma, P., Cheng, L. T. W., \& Leung, T. Y. (2020). Impact of political connections on Chinese export firms' performance - Lessons for other emerging markets. Journal of Business Research, 106(January 2018), 24-34. https://doi.org/10.1016/j.jbusres.2019.08.037.

[36] Tao, N. B., \& Hutchinson, M. (2013). Corporate governance and risk management: The role of risk management and compensation committees. Journal of Contemporary Accounting and Economics, 9(1), 83-99. https://doi.org/ 10.1016/ j.jcae.2013.03.003.

[37] Taylor, M., Thomas, A., Alexander, L. V, Craig, M., Gattuso, J. P., Jones, C., Mintenbeck, K., \& Wartenburger, R. (2018). Table of Contents. June, 1-243.

[38] Ufere, J., Buang, A., \& Uche, G. (2016). Determinants of voluntary carbon disclosure in the corporate real estate sector of Malaysia. Journal of Environmental Management, 182, 519-524.

https://doi.org/10.1016/j.jenvman.2016.08.011

[39] Wang, K., \& Pellegrini, M. M. (2019). Environment uncertainty and a firm's strategic change the moderating role of political connection and family ownership. https://doi.org/ 10.1108/JFBM-06-2019-0041.

[40] Wong, L., Bliese, P., \& McGurk, D. (2003). Military leadership: A context specific review. Leadership Quarterly, 14(6), 657-692. https://doi.org/10.1016/j.leaqua.2003.08.001. 